\title{
Outcome of self administered medical abortion pills by patients
}

\author{
Neelam Goyal ${ }^{1}$, Sanjay Kumar Goyal ${ }^{2 *}$
}

${ }^{1}$ Department of Obstetrics and Gynecology, ${ }^{2}$ Department of Urology, Lifeline Hospital and Urology Institute, Dehradun, Uttarakhand, India

Received: 04 October 2016

Revised: 07 October 2016

Accepted: 12 October 2016

\section{*Correspondence:}

Dr. Sanjay Kumar Goyal,

E-mail: drsanjayuro@yahoo.com

Copyright: () the author(s), publisher and licensee Medip Academy. This is an open-access article distributed under the terms of the Creative Commons Attribution Non-Commercial License, which permits unrestricted non-commercial use, distribution, and reproduction in any medium, provided the original work is properly cited.

\begin{abstract}
Background: Study of complication rate in patients presenting in Gynaec OPD after consuming self-prescribed medical abortion pills for unwanted pregnancies. Unchecked sale of Mifepristone and Misoprostol from pharmacies without prescription is giving rise to new emergencies in Gyn and Obs OPDs, which need to be urgently looked after by the authorities and public awareness regarding it's abuse.

Methods: 200 patients of reproductive age group from 17 yrs to 42 yrs over a period of 2 years from Apr 2014-Apr. 2016, who presented after consuming abortion pills, themselves, purchased over the counter from various pharmacies. Presenting complaints and complications were recorded and procedures required were analysed.

Results: Significant percentage of patients landing into severe anemia, sepsis, incomplete abortions. Two patients required surgery for ruptured ectopic and one diagnosed as hydatiform mole, 3 pregnancies continued to second trimester.

Conclusions: The high rate of medical complications occurring due to absence of medical surveillance of such patients and due to lack of protocol of Gynaec examination and ultrasound, it is highly recommended to have a better control over the unabated sale of these drugs at the pharmacies.
\end{abstract}

Keywords: Medical abortion, Abortion pills, Unwanted pregnancies

\section{INTRODUCTION}

Despite legal ban on sale of medical abortion pills (Mifepristone, Misoprostol) over the pharmacy counter directly to patients without prescription, is taking a high toll on health of reproductive age group females. ${ }^{1}$ This is due to illegal sale by chemists without prescription and Patient's consume these drugs without knowing the health hazards of these drugs, if not taken under medical supervision and land up into considerable complications. ${ }^{2}$

It's seen in Gynaec OPD frequently that selfconsumption is being done by patients overlooking the gestational period of pregnancies. Prescription by nonallopath doctors, quacks, nurses is very common which is often erratic and adding on this menace. Our colleagues of the same faculty need to address these problems to the authorities and increase public awareness regarding its abuse. ${ }^{3}$

\section{METHODS}

Retrospective study of 200 female patients presenting with complications due to self-consumption of abortion pills without prescription from Apr. 2014 to Apr. 2016. A detailed history of complaints and duration at which the abortion pills were taken, were recorded. Investigations and ultrasound were done for the patients. All the procedures which were required for these complications were analysed. 
Table 1: Patients presentation profile.

\begin{tabular}{|llll|}
\hline Age & No. of patients & Period of gestation (pills taken) & Complaints \\
\hline$<19$ Yrs & 20 & 6 weeks & Heavy bleeding P/V \\
\hline 20-24 Yrs & 50 & 6-9 weeks & Irregular bleeding, Pain abdomen \\
\hline 25-29 yrs & 80 & 5-12weeks & Bleeding, Continued pregnancy in 2 \\
\hline 30-34 yrs & 20 & 5-12weeks & Irregular bleeding, Pain, Profuse haemorrhage \\
\hline 35-39yrs & 26 & $5-11$ weeks & Profuse bleeding, Pain \\
\hline$>40$ Yrs & 04 & 5-9weeks & Profuse bleeding, Pain \\
\hline
\end{tabular}

\section{RESULTS}

Total 200 patients who had consumed mifepristone and misoprostol purchased without prescription and reporting to gynae OPDs with various complaints. Significant percentage of patients landing into severe anemia, sepsis, incomplete abortions. Two patients required surgery for ruptured ectopic and one diagnosed as hydatiform mole and 3 pregnancies continued to second trimester as observed in Table 2 .

Table 2: Complaints and procedure required.

\begin{tabular}{|c|c|c|c|}
\hline No & Complications & Percentage & $\begin{array}{l}\text { Treatment } \\
\text { received }\end{array}$ \\
\hline 1. & $\begin{array}{l}\text { Incomplete } \\
\text { abortion }\end{array}$ & $75 \%$ & Evacuation \\
\hline 2. & $\begin{array}{l}\text { Shock due to } \\
\text { profuse } \\
\text { bleeding }\end{array}$ & $04 \%$ & $\begin{array}{l}\text { Evacuation, Blood } \\
\text { transfusion }\end{array}$ \\
\hline 3. & $\begin{array}{l}\text { Ectopic } \\
\text { pregnancy }\end{array}$ & $02 \%$ & $\begin{array}{l}\text { Surgical } \\
\text { management }\end{array}$ \\
\hline 4. & $\begin{array}{l}\text { Hydatiforum } \\
\text { mole }\end{array}$ & $01 \%$ & $\begin{array}{l}\mathrm{D} \text { and } \mathrm{C}, \text { Blood } \\
\text { transfusion, Biopsy }\end{array}$ \\
\hline 5. & Sepsis & $05 \%$ & Antibiotic, D and C \\
\hline 6. & Severe anaemia & $60 \%$ & $\begin{array}{l}\text { Oral haematimnics, } \\
\text { Blood trans }\end{array}$ \\
\hline 7. & $\begin{array}{l}\text { Continued } \\
\text { pregnancy }\end{array}$ & $03 \%$ & $\begin{array}{l}\mathrm{II}^{\text {nd }} \text { trimester } \\
\text { termination }\end{array}$ \\
\hline
\end{tabular}

\section{DISCUSSION}

Unwanted pregnancy is still very common in Indian reproductive age females, forcing them to resort to medical abortion pills, purchased without prescription, landing them into various health hazards and life threatening emergencies. Without medical surveillance, examination and ultrasound the complication rates multiply many fold, poor strata females in order to avoid medical bills, frequently get involved in this health hazard. ${ }^{2}$ These abortion pills are not taken according to the protocol which leads to significant number of incomplete abortions and continued pregnancy. 3,4 Spreading of public awareness in media, conferences, seminars, ladies clubs and patients visiting us about selfconsumption of these drugs leading to their abuse and health hazards is the need to the day. ${ }^{5}$ The sale of these drugs at pharmacies without prescription should be regulated and checked. ${ }^{6-9}$ Many a times important aborted tissue for histopathology in hydatiform mole is lost due to bleeding at home and patients presenting later at Gynaic OPD, pregnancies, continuing to persist even after pills leading to $2^{\text {nd }}$ trimester abortions with its added health hazard is also very common. ${ }^{10-15}$

\section{CONCLUSION}

Patients should visit Gynaecologist for all unwanted pregnancies so that medical investigation protocol can be followed before medical abortion. The complication rate is too high to be ignored.

Funding: No funding sources

Conflict of interest: None declared

Ethical approval: The study was approved by the Institutional Ethics Committee

\section{REFERENCES}

1. Creinin MD. Medical abortion regimens: historical context and overview. Am J Obstet Gynecol 2000;183:(2):S3-S2.

2. Jones RK, Henshaw SK. Mifepristone for early medical abortion: Experiences in France, Great Britain and Sweden. Perspect Sex Reprod Health. 2002;34:154-61.

3. Grimes DA. Risks of mifepristone abortion in context. Contraception. 2005;71:161.

4. Atrash HK, Hogue CJ. The effect of pregnancy termination on future reproduction. Baillieres Clin Obstet Gynaecol. 1990;4:391-405.

5. Frank PI, McNamee R, Hannaford PC, Kay CR, Hirsch S. The effect of induced abortion on subsequent pregnancy outcome. $\mathrm{Br} \quad \mathrm{J}$ Obstet Gynaecol. 1991;98:1015-24.

6. Kruse B, Poppema S, Creinin MD, Paul M. Management of side effects and complications in medical abortion. Am J Obstet Gynecol. 2000;183:(2):S65-75.

7. Current trends ectopic pregnancy-United States, 1990-1992. Atlanta: Centers for Disease Control and Prevention, January 1995.

8. Bouyer J, Coste J, Shojaei T. Risk factors for ectopic pregnancy: a comprehensive analysis based on a 
large case-control, population-based study in France. Am J Epidemiol. 2003;157:185-94.

9. Knudsen UB. First trimester abortion with mifepristone and vaginal misoprostol. Contraception 2001;63:247-50.

10. Christensen K, Schmidt MM, Vaeth M, Olsen J. Absence of an environmental effect on the recurrence of facial-cleft defects. N Engl J Med. 1995;333:161-4.

11. International Classification of Diseases (ICD) online. Geneva: World Health Organization. (Accessed July 20 , 2007 ,

at http://www.who.int/classifications/icd/en/.)

12. Olsen J, Melbye M, Olsen SF. The Danish National Birth Cohort-its background, structure and aim. Scand J Public Health. 2001;29:300-7.
13. World Health Organization Task Force on PostOvulatory Methods of Fertility Regulation. Medical abortion at 57 to 63 days' gestation with a lower dose of mifepristone and gemeprost: a randomized controlled trial. Acta Obstet Gynecol Scand 2001;80:447-51.

14. Chen A, Yuan W, Meirik O. Mifepristone-induced early abortion and outcome of subsequent wanted pregnancy. Am J Epidemiol. 2004;160:110-7.

15. Chow WH, Daling JR, Cates W, Greenberg RS. Epidemiology of ectopic pregnancy. Epidemiol Rev. 1987;9:70-94.

Cite this article as: Goyal N, Goyal SK. Outcome of self administered medical abortion pills by patients. Int J Reprod Contracept Obstet Gynecol 2016;5:3740-2. 